\title{
PREINTERVENSI PENGENDALIAN VEKTOR NYAMUK (NON- INSEKTISIDA) DI LINGKUNGAN PANTI ASUHAN SANTO THOMAS
}

\author{
Cynthia Tjitradinata ${ }^{1}$ \\ Mauritio Aldo Laksono2, Delvi Monica Fymbay², \\ Yohana Bure Ditha Pratiwi ${ }^{2}$, Christyaningsih A.G. Juliandari ${ }^{2}$ \\ ${ }^{1}$ Program Fieldlab Fakultas Kedokteran UNIKA Soegijapranata, Semarang, Indonesia \\ ${ }^{2}$ Program Pendidikan Dokter Fakultas Kedokteran UNIKA Soegijapranata, Semarang, Indonesia \\ Korespondensi Penulis: \\ Nama : Cynthia Tjitradinata \\ Alamat : Citragrand Cluter Greenstone Blok O No. 5 \\ Nomor Telepon : 081327772666 \\ Email : cynthia@unika.ac.id
}

\begin{abstract}
Abstrak
Latar Belakang : Vektor borne disease merupakan infeksi penyakit yang disebabkan oleh patogen yang ditransmisikan oleh antropoda termasuk nyamuk dan lalat. Kondisi lingkungan yang memiliki sanitasi kurang memadai juga menjadi faktor yang mendukung tempat perkembangbiakan nyamuk. Salah satu upaya pengendalian penyakit menular yang murah dan aman ialah pengendalian vektor perantara penyakit. Metode pengendalian vektor berbasis perubahan lingkungan (non insektisida) saat ini cukup efektif.

Tujuan Penelitian : Mengukur tingkat pemahaman dan perubahan perilaku terhadap pengendalian vektor di Panti Asuhan Santo Thomas.

Desain Penelitian : Desain penelitian preeliminary study. Teknik sampling purposive sampling dengan populasi sampel penghuni panti asuhan Panti Asuhan Santo Thomas Ungaran. Waktu penelitian pada bulan April 2021 sampai Juli 2021. Pengumpulan data melalui metode observasi dan menyusun instrumen kuesioner.

Hasil : Berdasarkan analisis dari permasalahan, peneliti temukan pada Panti Asuhan Santo Thomas Ungaran yaitu terdapat barang - barang yang menumpuk pada lorong - lorong ruangan yang ada pada Panti yang dapat menjadi vektor penyebab penyakit.

Kesimpulan : Peneliti melakukan edukasi terkait pengendalian vektor berbasis pengendalian lingkungan (non insektisida). Hasil preintervensi yang peneliti lakukan ditemukan bahwa pengendalian lingkungan dinilai efektif dan efisien dalam pengendalian vektor di Panti Asuhan Santo Thomas. Penelitian selanjutnya disarankan mengembangkan pilot study untuk membandingkan efek intervensi melalui field trial.
\end{abstract}

Kata kunci: Vector Borne Disease, pengendalian vector, non insektisida

\section{Pendahuluan}

Kejadian penyakit yang diperantarai oleh vektor banyak dijumpai di negara tropis seperti di Indonesia. Kondisi ini menyebabkan meningkatnya kasus penyakit yang berkaitan dengan vektor borne disease (VDB). Vektor borne disease merupakan infeksi penyakit yang disebabkan oleh patogen yang ditransmisikan oleh antropoda termasuk nyamuk dan lalat. ${ }^{1}$ Beberapa spesies nyamuk yang banyak ditemukan di Indonesia adalah Sp. Aedes Aegypti, Sp.Anopheles, Sp.Culex. 
Spesies Aedes Aegypty adalah salah satu yang paling sering menularkan penyakit ke manusia seperti dengan mentransmisikan virus dengue yang menyebabkan penyakit demam berdarah dengue (DBD); sp.Anopheles menularkan plasmodium penyebab malaria terutama di daerah endemik; dan sp.Culex yang berkembangbiak di air kotor dan menjadi vektor untuk penyakit filariasis, West Nile fever, dan demam zika. ${ }^{1,2,3}$

Selain kondisi iklim tropis yang baik untuk perkembangbiakan vektor, kondisi lingkungan yang memiliki sanitasi kurang memadai juga menjadi faktor yang mendukung tempat perkembangbiakan nyamuk. ${ }^{3,4}$ Biasanya nyamuk berkembang biak di lingkungan yang tidak rapi maupun genangan air., ${ }^{2,3}$ Hasil survei lapangan yang dilakukan oleh peneliti pada periode bulan April - Juli tahun 2021, kondisi kebersihan lingkungan di Panti Asuhan Santo Thomas Ungaran masih terbilang kurang baik dan kurang rapi, dikarenakan banyak terdapat tumpukan barang yang berpotensi menjadi tempat berkembangbiaknya nyamuk. Selain itu, peneliti juga mengidentifikasi beberapa beberapa perilaku penghuni panti yang berpotensi meningkatkan frekuensi kontak penghuni panti dengan vektor nyamuk.

Salah satu upaya pengendalian penyakit menular yang murah dan aman ialah pengendalian vektor perantara penyakit. Upaya pengendalian vektor harus didasari oleh pemahaman yang memadai tentang bionomik vektor yang mencakup tempat perkembangbiakan, tempat istirahat, serta tempat kontak vektor dan manusia., ${ }^{4,5}$ Metode pengendalian vektor berbasis perubahan lingkungan fisik (non insektisida) saat ini cukup efektif. Upaya pengendalian melalui pengubahan lingkungan fisik dapat dilakukan agar vektor tidak dapat berkembangbiak. ${ }^{5,79}$ Selain itu, dibutuhkan juga penguatan dari aspek perilaku penghuni panti agar tidak terjadi kontak dengan vektor. Namun demikian keterbatasan data awal untuk penguatan perilaku pengedalian vektor di lingkungan panti harus segera teratasi. Oleh karena itu, diperlukan studi preintervensi untuk mengukur dan mengidentifikasi potensi dan hambatan upaya pengendalian vektor. Tujuan penelitian ini untuk mengukur tingkat pemahaman dan perubahan perilaku terhadap pengendalian vektor di panti Asuhan Santo Thomas setelah intervensi.

\section{Metode}

Desain Penelitian ini merupakan jenis penelitian preeliminary study merupakan studi pendahulan untuk menyempurnakan intervensi dan penyerapannya. Teknik sampling purposive sampling dengan populasi sampel penghuni panti asuhan Panti Asuhan Santo Thomas Ungaran. 
Kriteria inklusi adalah penghuni panti asuhan yang dapat komunikasi dengan baik serta menjawab kuosioner berusia mulai 10 tahun dan bersedia terlibat dalam proses intervensi yang dilakukan. Kriteria ekslusi adalah penghuni panti asuhan yang tidak dapat berkomunikasi dengan baik dan tidak bersedia terlibat dalam proses intervensi. Waktu penelitian pada bulan April 2021 sampai Juli 2021. Pengumpulan data melalui metode observasi dan menyusun instrumen kuosioner untuk mengetahui lingkungan panti. Metode observasi yang digunakan adalah observasi nonpartisipasi yaitu peneliti hanya sebagai pengamat objek yang akan diteliti, tanpa terlibat secara langsung. Instrumen kuosioner disusun terlebih dahulu meliputi profil panti asuhan, profil lingkungan panti asuhan, masalah kesehatan di panti asuhan dan perilaku hidup bersih sehat di panti asuhan. Analisis data secara deskriptif tentang perilaku hidup bersih sehat penghuni panti dan kebersihan lingkungan tempat tinggal serta intervensi pengendalian vektor dengan metode edukasi. Penilaian pengetahuan menggunakan kuosioner yang berjumlah 9 pertanyaan dengan teknik closed ended question dengan formula maksimum nilai bobot adalah $\mathrm{n} \times 1$ dan minimum nilai bobotnya adalah n x 0. Penilaian perilaku menggunakan kuosioner yang berjumlah 6 pertanyaan dengan teknik closed ended question dengan formula maksimum nilai bobot adalah $\mathrm{n} \times 1$ dan minimum nilai bobotnya adalah $\mathrm{n} \times 0$.

\section{Insiasi Intervensi: Edukasi Kesehatan}

Dalam penelitian ini, peneliti mengembangkan program intervensi untuk mengatasi masalah kesehatan yang ditemukan di Panti Asuhan Santo Thomas Ungaran berjudul "Pengendalian Nyamuk Non Insektisida". Intervensi ini memiliki aktifitas berupa penyuluhan dan edukasi kesehatan pencegahan perkembangbiakan vektor dengan metode 4M (Menguras tempat penyimpanan air, Menutup tempat penampungan air, Mengubur barang bekas yang dapat menampung air, Memantau wadah air yang berpotensi menjadi sarang nyamuk), menggunakan ikan kecil pada kolam untuk membasmi jentik nyamuk, serta memberikan poster mengenai lingkungan yang bersih dan sehat, serta bagaimana cara menjaga agar lingkungan tetap bersih dan sehat. Cara agar menjaga lingkungan tetap bersih dan sehat yaitu rajin membersihkan ruangan, membuang sampah pada tempatnya, tidak membuat tumpukan barang, serta melakukan pencegahan dan pembasmian nyamuk dengan 4M (Menguras, Menutup, Mengubur, dan Memantau). Pelaksanaan intervensi dilakukan secara online karena sedang kondisi pandemi dan dalam masa Pemberlakuan Pembatasan Kegiatan Masyarakat (PPKM) darurat. Pelaksanaan edukasi kesehatan secara online dilakukan pada bulan Juli 2021. Waktu yang diperlukan kurang 
lebih 2 jam, dengan jumlah peserta 25 orang. Setelah intervensi, 1 bulan kemudian dilakukan penilaian hasil intervensi dengan survei berdasarkan indikator penilaian untuk menilai pehamanan anak panti dan perilaku pengendalian vektor di Panti Asuhan Santo Thomas.

\section{Hasil}

\section{Karakteristik Populasi}

Tahun 2021, jumlah penghuni Panti Asuhan Santo Thomas Ungaran sebanyak 30 orang yang terdiri dari anak-anak di bawah lima tahun dan juga beberapa pendamping yang membantu menjaga dan membimbing para penghuni Panti Asuhan Santo Thomas Ungaran. Namun pertimbangan kemampuan komunikasi dan pemahaman maka peneliti hanya melibatkan penghuni panti mulai dari usia 10 tahun sebagai responden penelitian sesuai dengan kriteria inklusi penelitian.

Tabel 1. Karakteristik Anggota Panti

\begin{tabular}{lccc}
\hline No & Kelompok Umur & Jumlah & Keterangan \\
\hline 1. & $0-5$ tahun & 1 & penghuni \\
\hline 2. & $6-12$ tahun & 8 & penghuni \\
\hline 3. & $13-16$ tahun & 9 & penghuni \\
\hline 4. & 17 tahun ke atas & 12 & pendamping \\
\hline
\end{tabular}

Tabel 2. Karakteristik responden penelitian

\begin{tabular}{ccc}
\hline No & Kelompok Usia & Jumlah \\
\hline 1. & $10-12$ tahun & 4 \\
\hline 2. & $13-16$ tahun & 9 \\
\hline 3. & 17 tahun ke atas & 12 \\
\hline
\end{tabular}




\section{Karakteristik Tempat Tinggal}

Berdasarkan hasil observasi peneliti kondisi tempat tinggal Panti Asuhan Santo Thomas Ungaran, untuk kebersihan di sekitar tempat tinggal kemudian ketersediaan air bersih yang cukup, serta ventilasi sebagai jalan untuk pertukan udara dari luar ke dalam rumah sudah sangat bagus. Anak - anak yang berada di Panti Asuhan Santo Thomas Ungaran sudah memiliki inisiatif serta sangat disiplin dalam menjaga kebersihan tempat tinggalnya. Panti Asuhan Santo Thomas Ungaran memiliki jumlah kamar mandi 11 yang dimana 3 kamar mandi laki-laki dan 8 kamar mandi perempuan. Ketersediaan toilet dimana ada 2 toilet laki-laki dan 9 toilet perempuan. Lingkungan Panti Asuhan Santo Thomas terdapat ruang tamu, ruang komputer, perpustakaan, ruang doa, kapel, ruang belajar digabung dengan ruang makan, ruang setrika, ruang cuci piring, ruang dapur, dan juga terdapat tanaman hijau.

\section{Personal Hygiene}

Kesehatan personal penghuni Panti Asuhan Santo Thomas Ungaran, penghuni panti sudah menerapkan praktik hidup bersih dan sehat mendasar seperti menggosok gigi, mandi dua kali sehari, dan mencuci tangan dengan baik dan benar. Selain itu, pihak Panti Asuhan Santo Thomas juga mendukung kesehatan penghuninya dengan menyediakan layanan kesehatan yang baik dan rasa nyaman saat penghuni beristirahat

\section{Faktor Resiko: Tempat Perkembangbiakan Vektor}

Berdasarkan faktor resiko yang melatar belakangi analisis dari permasalah yang peneliti temukan pada Panti Asuhan Santo Thomas Ungaran yaitu terdapat barang - barang yang menumpuk pada lorong - lorong ruangan yang ada pada Panti, yang menyebabkan sakit yang umumnya sering terjadi pada anak - anak di Panti Asuhan St. Thomas Ungaran berupa batuk, pilek, dan flu. Tumpukan barang yang berlebihan dan tidak terurus dapat menjadi wadah atau tempat berkembang biaknya virus dan bakteri. Dikarenakan banyak anak - anak yang tinggal dalam Panti dan juga mereka tinggal diatap yang sama dan saling bertemu satu dengan yang lain tiap harinya, memudahkan penyebaran virus terjadi pada anak - anak di sana. Selain itu ada satu hal juga yang harus di perhatikan pada Panti Asuhan Santo Thomas Ungaran yaitu menguras bak kamar mandi dan tidak meninggalkan genangan air di kamar mandi yang akan menjadikan berkembang biaknya sarang jentik - jentik nyamuk. Hal ini dikarenakan sebelumnya dulu pernah ada anak panti yang terkena demam berdarah, hal ini dapat menjadi faktor resiko hal tersebut. 


\section{Penilaian Hasil Intervensi}

Penilaian hasil intervensi untuk menilai tingkat pehamanan setelah diberikan edukasi dan mengidentifkasi ada tidaknya tambahan pengetahuan dan perubahan perilaku setelah dilakukan intervensi. Setelah dilakukan intervensi peneliti membandingkan nilai post dengan baseline data sebelum dilakukan intervensi.

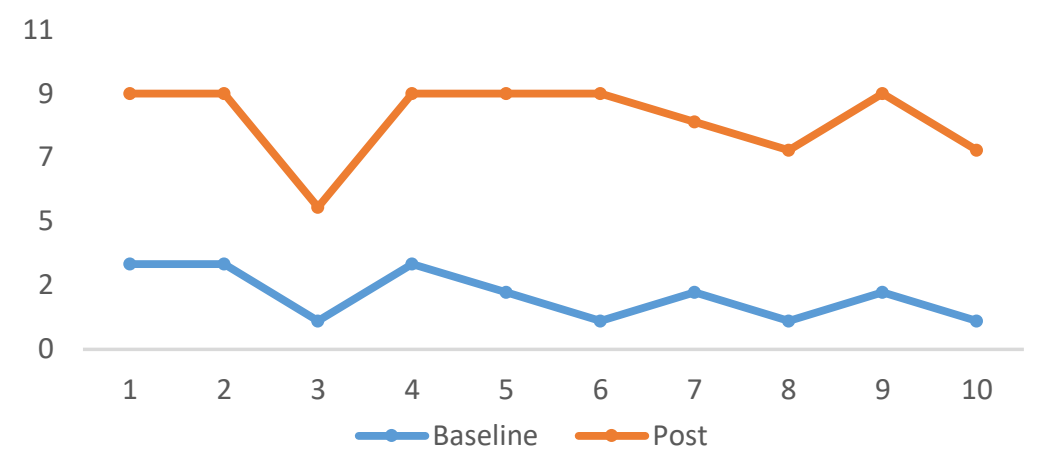

\section{Grafik 1. Perubahan Skor Pengetahuan Sesudah Intervensi}

Grafik 1 di atas menunjukkan perubahan pehamanan penghuni panti antara sebelum dan sesudah edukasi. Penilaian hasil intervensi melalui survei. Setelah dilakukan edukasi terjadi perbaikan pengetahuan terutama penyebab penyakit akibat gigitan nyamuk serta pencegahannya akan tetapi masih didapatkan kurangnya pehamanan mengenai tempat berkembang biaknya nyamuk.

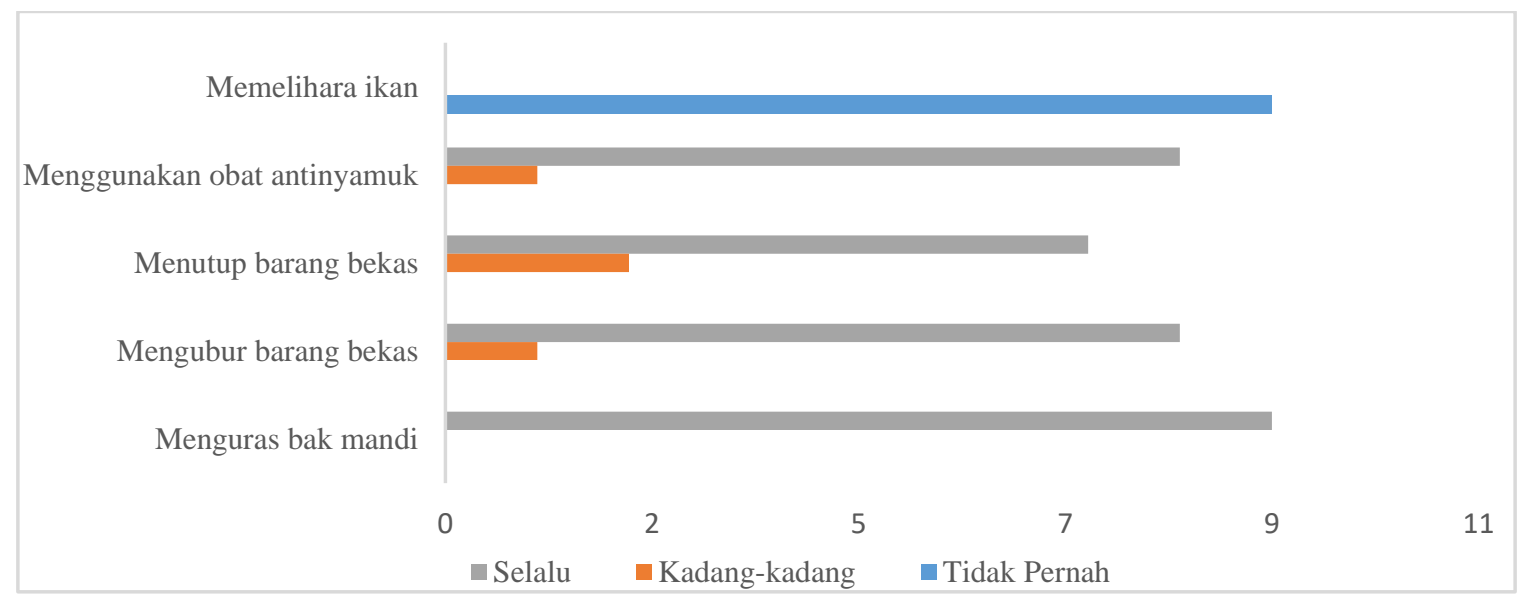

Grafik 2. Penilaian perubahan perilaku setelah 1 bulan intervensi

Berdasarkan hasil penilaian intervensi menunjukkan bahwa penghuni asrama tidak pernah memelihara ikan dalam pengendalian vektor sedangkan pengendalian vektor yang lain seperti 
menggunakan obat anti nyamuk, menutup barang bekas, mengubur barang bekas dan menguras kamar mandi sebagian besar sudah dilakukan.

\section{Diskusi}

Permasalahan yang terdapat pada Panti Asuhan Santo Thomas Ungaran mencakup barang yang bertumpukan di Lorong yang dapat menjadi tempat berkembang biaknya nyamuk. Panti Asuhan Santo Thomas Ungaran memiliki permasalahan penyakit yang sering terjadi pada anak anak di panti yaitu Demam berdarah Dengue (DBD). Besar kemukinan hal ini disebabkan banyaknya barang - barang yang bertumpukan di lorong menjadi sarang bagi nyamuk berkembang. Berdasarkan permasalahan tersebut, peneliti berfokus pengendalian vektor berbasis pengelolaan lingkungan (non insektisida) di Panti Asuhan Santo Thomas Ungaran.

Penelitian Wilson AL et al. menyatakan vector borne disease (VBD) adalah infeksi yang disebabkan oleh patogen melalui antropoda seperti nyamuk dan lalat. Pengelolaan lingkungan sebagai alat utama untuk mengendalikan VBD. Sebelum penggunaan insektisida, pengendalian VBD umumnya mengandalkan pemahaman vektor lokal meliputi ekologi perilaku dan kontrol lingkungan yang disesuaikan dan memerlukan tenaga kerja intensif. ${ }^{2}$ Fokus pengendalian vektor adalah pada eliminasi vektor nyamuk, terutama dengan mengubah habitat perairan tempat vektor berkembang. 2,4

Menurut Peraturan Menteri Kesehatan no 50 tahun 2017 tentang Standar Baku Mutu Kesehatan Lingkungan dan Persyaratan Kesehatan untuk Vektor dan Binatang Pembawa Penyakit Serta Pengendaliannya ditujukan untuk menurunkan populasi Vektor dan Binatang Pembawa Penyakit serendah mungkin, sehingga keberadaannya tidak lagi berisiko untuk terjadinya penularan penyakit di suatu wilayah. ${ }^{1}$ Pengendalian nyamuk dilakukan dengan pendekatan pengurangan sumber (source reduction), pengelolaan lingkungan (environmental management), dan perlindungan pribadi (personal protection).Pengelolaan lingkungan (environmental control) dapat dilakukan dengan cara mengelola lingkungan (environmental management), yaitu memodifikasi atau memanipulasi lingkungan sehingga terbentuk lingkungan yang tidak cocok (kurang baik) yang dapat mencegah atau membatasi perkembangan vektor. ${ }^{5,6,7}$, Cara ini berkaitan dengan pembersihan atau pemeliharaan sarana fisik yang telah ada supaya tidak terbentuk tempattempat perindukan atau tempat istirahat vektor. ${ }^{8,9}$ 
Penelitian Singh $\mathrm{R}$ et al. menyatakan bahwa pengendalian vektor bertujuan untuk membatasi penularan patogen dengan mengurangi atau menghilangkan kontak manusia dengan vektor. Kegiatan-kegiatan ini memiliki keuntungan penting dibandingkan operasi pengendalian vektor langsung untuk bertahan lama atau bahkan permanen dalam efeknya sehingga memungkinkan keseimbangan biaya dan manfaat yang positif. ${ }^{10}$ Untuk mengadopsi lingkungan dengan tepat investigasi lapangan praktik manajemen harus dilakukan terlebih dahulu untuk mengkarakterisasi dan geo-referensi tempat berkembang biak. ${ }^{11}$

Setelah dilakukan intervensi didapatkan terjadi peningkatan pemahaman tentang upaya pengendalian vektor berbasis lingkungan. Namun, masih terdapat penghuni panti yang kurang memahami tempat berkembang biaknya nyamuk. Dimana nyamuk dapat berkembang biak tidak hanya di tumpukan barang dan genangan air tetapi juga bak mandi karena itu harus diberikan tambahan edukasi mengenai menjaga kebersihan lingkungan termasuk juga membersihkan kamar mandi secara rutin agar tidak menjadi sarang jentik - jentik nyamuk. Skor penilaian yang rendah kemungkinkan disebabkan materi tersebut belum banyak disampaikan dan disampaikan dalam waktu yang singkat. Berdasarkan hasil penilaian intervensi terhadap perubahan perilaku setelah 1 bulan diberikan edukasi menunjukkan bahwa penghuni asrama tidak pernah memelihara ikan dalam pengendalian vektor sedangkan pengendalian vektor yang lain seperti menggunakan obat anti nyamuk, menutup barang bekas, mengubur barang bekas, penggunaaan abate dan menguras kamar mandi sebagian besar sudah dilakukan. Hal ini disebabkan panti tidak memiliki kolam ikan dan sulitnya dalam memelihara ikan karena keterbatasan sarana dan personal.

\section{Keterbatasan dan usulan Perbaikan}

Keterbatasan dalam penelitian ini adalah penelitian ini karena kondisi pandemi sehingga membatasi kami dalam edukasi secara langsung, kami hanya bisa bertemu penghuni panti yang berusia mulai usia 13 tahun saat kunjungan dan edukasi dilanjutkan dengan googlemeet secara online untuk penghuni yang berusia di bawah 13 tahun sehingga bisa saja terjadi bias saat penyampaian informasi. Namun walaupun penelitaian ini menggunakan jumlah sampel yang sedikit dan dilaksanakan di satu panti asuhan namun temuan utama dalam penelitian bisa dijadikan sebagai dasar pengembangan pilot study pengendalian vektor nyamuk dengan pemberdayaan perubahan perilaku penghuni panti. 


\section{Kesimpulan}

Panti Asuhan Santo Thomas memiliki fasilitas yang memadai dan memiliki potensi untuk menjaga lingkungan tetap bersih, tetapi hal tersebut kurang diaplikasikan seperti adanya tumpukan buku dan barang yang tidak terpakai, hal ini bisa menjadi vektor penyebab penyakit. Maka dari itu, peneliti melakukan edukasi terkait pengendalian vektor berbasis pengendalian lingkungan (non insektisida). Hasil preintervensi yang peneliti lakukan ditemukan bahwa pengendalian lingkungan dinilai efektif dan efisien dalam pengendalian vektor di Panti Asuhan Santo Thomas. Penelitian selanjutnya disarankan mengembangkan pilot study untuk membandingkan efek intervensi melalui field trial.

\section{Persetujuan Etik}

Penelitian ini tidak menggunakan ethical clearance karena merupakan penelitian pendahuluan.

\section{Ucapan Terima Kasih}

1. Universitas Soegipranata Semarang yang sudah memberikan dana sehingga kegiatan penelitian bisa terlaksana.

2. Pengelola Panti Asuhan Santo Thomas Ungaran yang sudah memberikan izin pada tim peneliti bersedia menjadi responden dan bersedia berpartisipasi dalam program intervensi.

3. Koordinator dan tim Field Lab Fakultas Kedokteran Universitas Soegipranata Semarang.

\section{Daftar Pustaka}

1. Kementrian Kesehatan Republik Indonesia. Rencana Aksi Kegiatan Pencegahan dan Pengendalian Penyakit Tular Vektor dan Zoonotik Tahun 2015-2019. Direktorat Jendal Pencegahan dan Pengendalian. Direktorat Jenderal Pencegahan dan Pengendalian Penyakit Tahun 2017.

2. Wilson AL, Courtenay O, Kelly-Hope LA, Scott TW, Takken W, Torr SJ, et al. (2020) The importance of vector control for the control and elimination of vector-borne diseases. PLoS Negl Trop Dis 14(1): e0007831. https://doi.org/10.1371/ journal.pntd.0007831

3. Pathak V, Mohan M. A notorious vector-borne disease: Dengue fever, its evolution as public health threat. J Family Med Prime Care. 2019;8(10): 3125 - 3129.

4. Smith PG, Morrow RH R DA. Field Trials of Health Interventions: A Toolbox. 3rd Edition. OUP Oxford Editors. 2015. Chapter 13, Preliminary Studies And Pilot Testing. 
5. WHO. Vector-borne disease. March 2020. Available from : https://www.who.int/newsroom/fact-sheets/detail/vector-borne-diseases

6. Annashr Nissa, Rahmadi FM. Correlation of Knowledge and Attitude with Filariasis Prevention Practices in Cilimus Subdistrict Kuningan Regency. ASP. Juni 2021:13(1): 23-36

7. World Health Organization. Regional Office for South-East Asia. (2011). Comprehensive Guideline for Prevention and Control of Dengue and Dengue Haemorrhagic Fever. Revised and expanded edition. WHO Regional Office for South-East Asia. https://apps.who.int/iris/handle/10665/204894

8. Petersen L, Beard CB, and Visser N. Combatting the Increasing Threat of Vector-Borne Disease in the United States with a National Vector-Borne Disease Prevention and Control System. Am. J. Trop. Med. Hyg., 100(2), 2019, pp. 242-245 doi:10.4269/ajtmh.18-0841

9. Buhler C,Winkler V, Ranzinger SR, Boyce R ,Horstick O. Environmental methods for dengue vector control - A systematic review and metaanalysis. s. PLoS Negl Trop Dis 13(7):2019 https://doi.org/10.1371/journal. pntd.0007420

10. Singh R, Dhama K, Khandia R, Munjal A, Karthik K, Tiwari R, Chakraborty S, Malik YSi R. Prevention and Control Strategies to Counter Zika Virus, a Special Focus on Intervention Approaches against Vector Mosquitoes:Current Updates. Front. Microbiol. 9:87.2018

11. Bellini R, Zeller H, Bortel W. A review of the vector management methods to prevent and control outbreaks of West Nile virus infection and the challenge for Europe. Parasites \& Vectors 2014, 7:323 